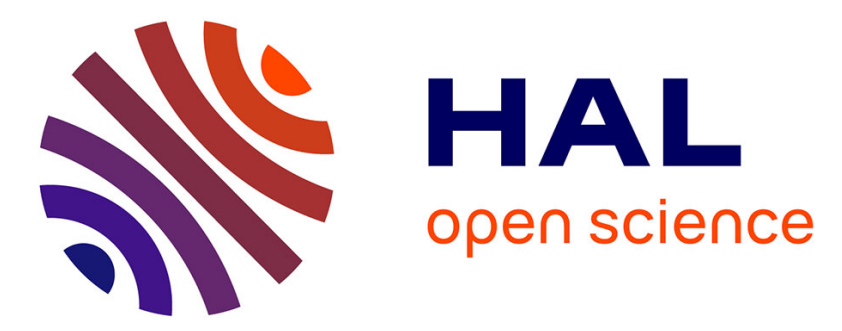

\title{
Mechanization and input reduction in processing tomato cropping : agronomic aspects, building and testing of appropriate technical ways of management
}

\author{
Y. Dumas
}

\section{- To cite this version:}

Y. Dumas. Mechanization and input reduction in processing tomato cropping: agronomic aspects, building and testing of appropriate technical ways of management. 3. International Symposium, Nov 1989, Avignon, France. hal-02777584

\author{
HAL Id: hal-02777584 \\ https://hal.inrae.fr/hal-02777584
}

Submitted on 4 Jun 2020

HAL is a multi-disciplinary open access archive for the deposit and dissemination of scientific research documents, whether they are published or not. The documents may come from teaching and research institutions in France or abroad, or from public or private research centers.
L'archive ouverte pluridisciplinaire HAL, est destinée au dépôt et à la diffusion de documents scientifiques de niveau recherche, publiés ou non, émanant des établissements d'enseignement et de recherche français ou étrangers, des laboratoires publics ou privés. 
MECHANIZATION AND INPUT REDUCTION IN PROCESSING TOMATO CROPPING : AGRONOMIC ASPECTS; BUILDING AND TESTING OF APPROPRIATE TECHNICAL WAYS OF MANAGEMENT

Y. DUMAS

Institut National de la Recherche Agronomique

Station d'Agronomie

B.P. 91, 84140 MONTFAVET

FRANCE

\section{Abstract}

This study deals with the agronomic feasibility and the results of mechanized ways of management for processing tomato which were likely to meet the following main objectives : a) field state suitable to mechanical harvest, b) satisfying yield (60 to $80 \mathrm{t.ha-1})$, c) input reduction. The agronomic contraints deriving from them and pluridisciplinary scientific results were used as a base of reasoning and then of building technical management schedules. Most of these contraints have been considered and integrated into ways of management of processing tomato crops in large plots durtng 3 years $(1985-86-87)$ on a clay alluvial soil. Management decistons were taken according to periodical simple diagnoses based on observing, counting or measuring. The main objectives were satisfied namely : 1) a total mechanization (except one or two partial hand weedings), with a reduced number of operations, 2) reduced fertilization : for $P$, in a poor soil, half of the current supplies and for $\mathrm{N}$ about one quarter, 3) reduced plant protection, including biological means, 4) good field fitness to mechanical harvest, 5) annual yields respectively : 78 , 75 and 50 t.ha-1. The results show that it is possible to produce otherwise and cheaper while reducing resources wasting and improving environment safety.

\section{Introduction}

In many countries growing processing tomatoes hand labour becomes more and more expensive. Silviero (1986) considered that it could represent 70 to $75 \%$ of production cost with $60 \%$ concerning hand harvest. Producers try to reduce it and turn more and more towards the mechanization of a maximum of cultural operations including harvest with the will to simplify tomato cropping. In the mediterranean area, this involves progressive adjustments of cropping systems. For mechanization development generally leads to important modiflcations in the concerned crops management (Sims, 1985). A successful once-over harvest and above all a mechanical one lead the producer to reconsider all the technical operations and their timing (Di Candilo et al..

Acta Horticulturae 277, 1990

Processing Tomatoes 
1987). An effort is needed for the creation or the adaptation of machines (Nicolas et al., 1987).

In the South of France, one of the possibilities for producers to keep processing tomato competitive lies in mechanizing but also in reducing production costs without much penalizing yield level. This implies that we produce in a better way through a better use of production factors.

So the present study deals with the agronomic feasability and results of mechanized ways of management which were likely to meet the following main objectives : a) fleld state suitable to mechanical harvest at the crop cycle end.

b) satisfying yield ( 60 to $80 \cdot \mathrm{ha}^{-1}$ ),

c) inputs reduction (energy, fertilizers, pesticides).

\section{Materials and methods}

Starting from previous experiments (Dumas et al., 1983) and surveys by farmers', we have built diagrams as a basis for the conception of technical ways of crop management adapted to the above objectives.

Figure 1 briefly presents the main agronomic contraints from point a). It shows that mechanical harvest choice completely structures the types of field operations which are to follow each other. These contraints lead to problems of technical choices or tactics. The weight of mechanical harvest greatly influences the choice of cultivars, which must combine many suitable characteristics (Stevens, 1979, Galban et al., 1978, Ruiz Altisent et al., 1980), but also of soil preparation, fertilization, crop timing as sowing date which influences harvesting date.

Figure 2 presents an example of contraints, above all through fertilization aspects, generated by points b) and c). This topic has induced specific studies. phosphorus placement was studied (Dumas, 1988) in order to increase young seedlings growth rate with moderate $P$ amounts, since $\mathrm{P}$ is expensive and easily becomes insoluble in many soils. Nitrogen supply was also studied (Dumas, unpublished) in field experiments which showed that: (i) supplies bigger than $100 \mathrm{~kg} \mathrm{~N}$ ha-1 induced a new plant branching before harvest and very high nitrate residues in the soil profile after harvest $(200-250 \mathrm{~kg} \mathrm{~N} \mathrm{ha-1}$ for $1 \mathrm{~m}$ deep), (ii) apparent soil mineralisation, during tomato crop and for $1 \mathrm{~m}$ deep, supplied 120-150 $\mathrm{kg}$ nitric $\mathrm{N}$ ha-1, (iii) without $\mathrm{N}$ supply tomato stand showed $N$ stress only after the appearance of the first trusses (beginning of high growth rate and root system still small). So taking into account soil nitrates residues at emergence time, $N$ supplies could be strongly reduced while making them available by placement. 
All these points have been considered and integrated into ways of management of crops experimented on large plots ( $2500 \mathrm{~m}^{2}$, replicated 3 or 4 times) during 3 years (1985-86-87) on an alluvial clay soil (table 1) near Avignon in the S.E. of France. Table 2 gives the main characteristics of the 3 year climate. The cultivar was Earlymech (UC82 from Petoseed). Field operations were carried out with an equipment mostly commonly used by farmers of the region.

Tomatoes were direct-seeded in May, after wheat. Hater supply was performed by sprinkler irrigation ( $8-9 \mathrm{~mm} \mathrm{~h}-1$ ) according to a balance between climatic demand, rainfal. and soil water reserve on the rooting depth. Potential evapotranspiration was daily calculated by Penman formula and rooting depth was estimated from previous studies, i.e. $15 \mathrm{~cm}$ at lst truss time, then $1.5 \mathrm{~cm} \mathrm{~d}^{-1}$ increase till end of flowering, then increase of $1.0 \mathrm{~cm} \mathrm{~d}^{-1}$ diminishing to 0 near harvest. Table 3 gives the successive values used for the crop coefficient Kc (ratio of crop maximum evapotranspiration to potential evapotranspiration). Water supply was decided when usable water reserve had decreased down to $40 \%$ of 1 ts maximum actual value. The last irrigation took place at the beginning of ripening time. Soil profile nitrate content was measured by soil sampling and ionometry at emergence time. Plant protection was decided as follows : for diseases, use of local official warnings and weekly field observation; for insects, during risky periods, weekly countings of aphids numbers with high-pressure spraying decision when 10 aphids per leaflet from young shoots for a 60 leaflets sample (Bues et al.. 1985), weekly countings of Heliothis armigera eggs and high-pressure spray when 2 eggs observed in a 50 leaves sample (Bues et al., 1988).

\section{Results}

Table 4 gives an example, for 1985 , of the successive operations performed on the fields. 1986 and 1987 were very similar with only one cultivator passage and small differences in plant protection: one insecticide spray (acephate against fruitworm) and two fungicides in 1986; one acephate and two Bacillus thuringiensis against fruitworm and two funglcide sprays in 1987; there never were any intervention against aphids. In 1986 and 1987 there were 12 irrigations with $327 \mathrm{~mm}$ and $359 \mathrm{~mm}$ respectively. The main objectives were satisfied namely :

\subsection{A total mechanization except partial hand weedings} Every field operation could be mechanized, with reducing the number of interventions to save time and energy e.g. few but rather early soil tilling operations (digging machine and one or two vibrating tine cultivator passages), $P$ placement while bed raising, N placement while mechanical weeding etc. But weed-control needed hand interven- 
tions. Main weeds were: Amaranthus retroflexus, Chenopodium album, Papaver rhoeas, Gallum asparine, Convolvulus arvensis, Cirsium arvense, Polygonum convolvulus, Solanum nigrum, Lepidium draba, Portulaca oleracea. Partial hand weeding was necessary in 1985 and 1986 on the row just after mechanical weeding, and on some areas at ripening time againgt solanum nigrum only.

\subsection{A reduced fertilization}

On an average, local farmers usually broadcast $150 \mathrm{~kg} \mathrm{~N}, 110 \mathrm{~kg} \mathrm{P}$ and $250 \mathrm{~kg} \mathrm{~K} \mathrm{ha-1.} \mathrm{Here} \mathrm{on} \mathrm{a} \mathrm{soll} \mathrm{very}$ poor in phosphorus, half $P$ was supplied, one quarter $N$ and no $K$; For each year, soil residual nitric $N$ content was comprised between 12 and $25 \mathrm{ppm}$ in the upper layer $0-20 \mathrm{~cm}$ corresponding to 30 to $60 \mathrm{~kg} \mathrm{~N}$ ha-l after emergence. So in our conditions 15 to 20 ppm nitric $N$ seemed sufficient for plant supply until the appearance of the first trugses. At that stage, we measured 80 to $100 \mathrm{~kg}$ nitric $\mathrm{N}$ ha-l on $40 \mathrm{~cm}$ deep and 150 to $200 \mathrm{~kg}$ on $1 \mathrm{~m}$ deep.

\subsection{Light plant protection}

Due to countings and observations, few pesticides interventions were performed. As a comparison, official warnings advised 8-10 fungicides in 1985 and 4 in 1986 and 7-8 insecticides in 1985 and 4 in 1986. High aphids populations were accepted on young plants kept vigorous owing to high growth rate ( $P$ availability). Bacillus thuringiensis was used as often as possible against fruitworm according to larvae development stage.

\subsection{A good crop fitness to mechanical harvest}

Red fruit percentage generaliy was over $90 \%$. Vegetation was half dried, soil structure was thin and present weeds without very tall individuals did not disturb harvest. Fruit losges varied from 1 to $5 \%$.

3.5. Yields were respectively 78,75 and 50 t ha-1 in 1985-86-87. 1987 worse yield could be explained by a non favourable climate, a seeding error ( 350 000 plants $\mathrm{ha}^{-1}$ instead of 120 000-150 000, without thinning possibility) and a deficient irrigating system (water excess). Nethertheless 1987 yield was not so bad on a local basis. Average fruit weight was about 50-60 $\mathrm{g}$ for 1985 and 1986 and 40-45 $g$ for 1987. Fruit technological characteristics were good : Ph 4.1 to 4.3 , refract. index 5.0 to 6.0 , dry solid content 6.0 to 6.5 .

\section{Discusgion}

These experiments, carried out in technical conditions very similar to farmers' and sometimes with harder human or time contraints. showed at evidence that input sparing is possible and can lead to satisfying results.

Without very much sophisticated equipment it was possi- 
ble to perform simultaneous field operations, which is interesting for time and energy use and allow substantial cost reduction (Conea et al., 1984). The bests results of input reduction were obtained for fertilization and plant protection. Fertilizer placement, with a simple equipment, considerably reduced the supplied amounts with a good result. For in 1985 and $1986, N$ uptake from soil reached about $200 \mathrm{~kg} \mathrm{ha}-1$. However a better knowledge of nutrients dynamics in soil and plant seems necessary to provide better decision arguments. For here the decision of supplying $40 \mathrm{~N} \mathrm{ha-l}$ was based on rather simple observations and an extension to other soil types has to be studied. By another way one must look after that such a management does not lead to a decrease of soll chemical fertility which has to be maintained through crop successions. For plant protection, interventions were also simplified, undoubtedly owing to well argued choices but also to climatic years rather unfavourable to mildew.

In fact it also clearly appeared that input reduction cannot be uniform for every point. For instance water requirements must be strictly satisfied during germination and emergence time (frequent irrigations needed on the present soil which is rapidly mulching on 2-3 cm deep with dry windy weather) and especially during flowering and fruit set time. In the same way various year types can induce changing number and intensity of sanitary problems. Weeds were badly controlled, and this can also be a reason of varying costs among years.

Important progress can be made in that way by producers who must give more time to observing and by researchers who must provide producers with suitable decision indicators rather easy to observe in order to ameliorate diagnosis and increase factors efficiency. Netherthelegs these results show that it is possible to produce otherwise and cheaper by a reasoned way, while reducing at the same time the wasting of various resources and improving environment safety and products quality.

\section{References}

Bues, R., Toubon, J.F., and Poitout, H.S., 1985. Elaboration d'une lutte raisonnee contre les pucerons (Macrosiphum euphorbiae Thomas et Mysus persicae Sulzer en cultures de tomates de conserve dans le sud-est de la France. Proc. workshop WPRS/OILB and EEC group on Integrated plant protection in field vegetables pp 15.

Bues, R., Toubon, J.F., Poitout, H.S., and Doudinhon, L., 1988. Dynamique des populations et lutte microbiologique contre la noctuelle de la tomate ( $H$. armigera). sous serres dans le sud de la France. P.H.M.-Rev. Hort. 285: $43-48$.

Conea, A., Jidav, L., Dumitrescu, M., and Marinescu, A., 1984. Posibilitati de reducere a consumului de carburanti Ia lucrartle mecanice specifice culturilor de legume. An. Inst. Cerc.Legum.Flor. VII:311-318. 
Di Candilo, M., and Casarini, B. 1987. Pomodoro da industria : motivazioni e tecniche per la meccanizzatione della raccolta. Inf. Agra. 8:29-69.

Dumas, Y., Vergniaud, P., and Bussieres, P., 1983. Présentation d'une etude expérimentale de divers modes de conduite de la tomate de plein champ dans differentes successions de cultures. In La fatigue des sols, 23ème colloque S.F.P.. Ed. I.N.R.A. Publ.:169-174.

Dumas, $Y, 1988$. Influence of phosphorus fertilization and availability on growing and production of sown tomatoes. Acta Hort. 220:245-252.

Galban, A.R., Korchakov, G.D., Sigarreta, A.. Piedra, S., and Hernandez, A., 1978. Estudio comparativo sobre lá resistencia que presentan los frutos de algunas variedades de tomates industriales a los danos mecanicos. Cienc.Tecn.Agric. 1(1):61-81.

Nicolas, D., Branthome, X., Siret, P., Susini, L., and Lyon, C., 1987. Progres dans la recolte de la tomate de conserve en France. Une nouvelle récolteuse de tomates. L'utilisation d'un conditionneur de végétation. Acta Hort. 200:133-143.

Ruiz Altisent, M. , Ortiz-Canavate, J., Juste Perez, J. and Rodriguez del Rincon, A., 1980. Fruit firmness and skin resistance of processing tomato varieties tested in $\mathrm{Ba}$ dajoz (Spain), related to mechanical harvesting. Acta Hort. $100: 281-296$.

Silviero, P., 1986. Il ruolo della diffusione della raccolta meccanica per la produzione del pomodoro da industria. Inf.Agra. $42(28): 29-34$.

Sims, W.L., 1985. Cultural modification of vegetables for Mechanized production. Hortscience 20(6):1005-1008.

Stevens, M.A.. 1979. Breeding tomatoes for processing. 1st international symposium on tropical tomato, Shanhua, Taïan: Asian Vegetable Research and Developpment Center : 201-213.

Table 1. Main soil characteristics

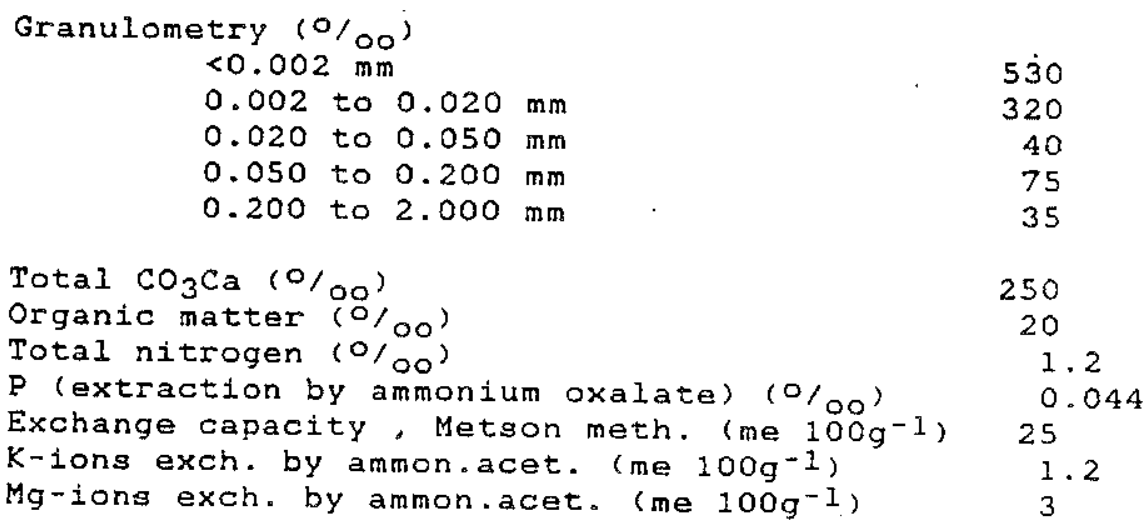


Table 2. Climate characterlstics for the cropping periods

\begin{tabular}{|c|c|c|c|c|c|c|c|c|c|c|}
\hline & & \multicolumn{3}{|l|}{1985} & \multicolumn{3}{|l|}{1986} & \multicolumn{3}{|l|}{1987} \\
\hline & & $T$ & PET & $P$ & $T$ & PET & $P$ & $\mathbf{T}$ & PET & $P$ \\
\hline May & $\begin{array}{l}1 \text { st dec } \\
2 \text { nd dec } \\
3 \text { id dec }\end{array}$ & $\begin{array}{l}12.9 \\
13.9 \\
18.6\end{array}$ & $\begin{array}{l}33 \\
28 \\
49\end{array}$ & $\begin{array}{r}38 \\
66 \\
0\end{array}$ & $\begin{array}{l}16.2 \\
19.1 \\
19.2\end{array}$ & $\begin{array}{l}35 \\
41 \\
59\end{array}$ & $\begin{array}{r}16 \\
0 \\
1\end{array}$ & $\begin{array}{l}13.2 \\
13.7 \\
17.1\end{array}$ & $\begin{array}{l}40 \\
38 \\
58\end{array}$ & $\begin{array}{r}5 \\
45 \\
0\end{array}$ \\
\hline June & $\begin{array}{l}\text { 1st dec } \\
\text { 2nd dec } \\
\text { 3rd dec }\end{array}$ & $\begin{array}{l}19.3 \\
18.6 \\
19.8\end{array}$ & $\begin{array}{l}43 \\
48 \\
52\end{array}$ & $\begin{array}{r}3 \\
11 \\
15\end{array}$ & $\begin{array}{l}17.0 \\
20.1 \\
23.6\end{array}$ & $\begin{array}{l}54 \\
50 \\
54\end{array}$ & $\begin{array}{r}0 \\
90 \\
0\end{array}$ & $\begin{array}{l}18.8 \\
18.3 \\
22.0\end{array}$ & $\begin{array}{l}46 \\
48 \\
59\end{array}$ & $\begin{array}{l}10 \\
21 \\
11\end{array}$ \\
\hline July & $\begin{array}{l}1 \mathrm{st} \text { dec } \\
2 \mathrm{nd} \text { dec } \\
3 \mathrm{rd} \text { dec }\end{array}$ & $\begin{array}{l}24.7 \\
24.0 \\
23.7\end{array}$ & $\begin{array}{l}59 \\
54 \\
59\end{array}$ & $\begin{array}{l}0 \\
0 \\
0\end{array}$ & $\begin{array}{l}23.6 \\
22.8 \\
23.8\end{array}$ & $\begin{array}{l}62 \\
69 \\
57\end{array}$ & $\begin{array}{l}2 \\
0 \\
0\end{array}$ & $\begin{array}{l}25.3 \\
22.1 \\
21.7\end{array}$ & $\begin{array}{l}55 \\
43 \\
63\end{array}$ & $\begin{array}{r}34 \\
56 \\
1\end{array}$ \\
\hline Aug & $\begin{array}{l}\text { lst dec } \\
\text { 2nd dec } \\
\text { 3rd dec }\end{array}$ & $\begin{array}{l}21 \cdot 1 \\
23 \cdot 1 \\
20.9\end{array}$ & $\begin{array}{l}49 \\
50 \\
43\end{array}$ & $\begin{array}{r}62 \\
0 \\
55\end{array}$ & $\begin{array}{l}25.1 \\
23.5 \\
19.9\end{array}$ & $\begin{array}{l}53 \\
47 \\
441\end{array}$ & $\begin{array}{r}0 \\
7 \\
128\end{array}$ & $\begin{array}{l}22.3 \\
26.2 \\
21.2\end{array}$ & $\begin{array}{l}54 \\
54 \\
38\end{array}$ & $\begin{array}{r}1 \\
0 \\
112\end{array}$ \\
\hline Sept & $\begin{array}{l}\text { 1st dec } \\
\text { 2nd dec } \\
3 r d \text { dec }\end{array}$ & $\begin{array}{l}21.8 \\
20.1 \\
21.3\end{array}$ & $\begin{array}{l}48 \\
32 \\
24\end{array}$ & $\begin{array}{l}0 \\
0 \\
0\end{array}$ & $\begin{array}{l}19.6 \\
21.0 \\
18.2\end{array}$ & $\begin{array}{l}39 \\
28 \\
23\end{array}$ & $\begin{array}{r}0 \\
53 \\
37\end{array}$ & $\begin{array}{l}21.9 \\
22.8 \\
19.0\end{array}$ & $\begin{array}{l}37 \\
28 \\
25\end{array}$ & $\begin{array}{r}2 \\
0 \\
51\end{array}$ \\
\hline
\end{tabular}

$T$ : mean air temperature for one decade $\left({ }^{\circ} \mathrm{C}\right)$

PET : potential evapotranpiration (Penman formula), sum for one decade ( $\mathrm{mm}$ )

$P$ : rainfall, sum for one decade $(\mathrm{mm})$

Table 3. Crop coefficient $K c$ used for crop maximum evapotranspiration (MET) calculation from potential evapotranspiration (PET)

\begin{tabular}{|c|c|c|c|c|c|}
\hline $\begin{array}{l}\text { Plant } \\
\text { gtage }\end{array}$ & emerg. & $\begin{array}{l}1-2 \text { trus. } \\
\text { /plant }\end{array}$ & $\begin{array}{l}3-4 \text { tr. } \\
\text { /pl. }\end{array}$ & $\begin{array}{l}\text { Ist } \\
\text { flow. }\end{array}$ & $\begin{array}{l}1 \text { tr. } \\
\text { with } \\
\text { fl. } / p i .\end{array}$ \\
\hline $\mathrm{Kc}=\mathrm{MET} / \mathrm{PET}$ & 0.3 & 0.4 & 0.5 & 0.6 & 0.8 \\
\hline
\end{tabular}

\begin{tabular}{|c|c|c|c|c|c|c|}
\hline $\begin{array}{l}\text { Plant } \\
\text { stage }\end{array}$ & $\begin{array}{c}\text { lst } \\
\text { fruits }\end{array}$ & & $\begin{array}{l}1 \text { tr. } \\
\text { with } \\
\text { fI./pI. }\end{array}$ & $\begin{array}{l}2 \text { tr. } \\
\text { with } \\
\text { fr./pI. } \\
\text { half flg }\end{array}$ & $\begin{array}{l}\text { half } \\
\text { fruit } \\
\text { set }\end{array}$ & $\begin{array}{c}\text { end } \\
\text { of } \\
\text { flowg }\end{array}$ \\
\hline $\mathrm{KC}=\mathrm{MET} / \mathrm{PET}$ & 1.0 & & 1.05 & 1.1 & 1.15 & 1.20 \\
\hline duration (days) & & 4 & 4 & 6 & & \\
\hline
\end{tabular}


Table 4. Technical operations performed in 1985

Digging machine on $20 \mathrm{~cm}, 29$ Oct 1984

40 p ha-1 (triple superphosphate) broadcasted, 2 Apr 1985

Diquat, 3 Apr

Vibrating tine cultivator, 23 Apr

Beds raising and placement of $20 \mathrm{p}$ ha-l under rows, $23 \mathrm{Apr}$

Direct-seeding and microgranulated insecticide placement on seeds, 30 Apr

Difenamid (3200 $\left.\mathrm{g} \mathrm{ha}^{-1}\right)$ † metribuzin (160 $\mathrm{g} \mathrm{ha}-1$ ), 6 May

Irrigation: 22 May: $9 \mathrm{~mm}-24$ May: $10 \mathrm{~mm}-28$ May: $20 \mathrm{~mm}$ 30 May: $10 \mathrm{~mm}-5 \mathrm{Jun}: 6 \mathrm{~mm}-21$ Jun: $10 \mathrm{~mm}-3 \mathrm{Jul}:$ $38 \mathrm{~mm}$ - $10 \mathrm{JuI}: 58 \mathrm{~mm}-16 \mathrm{JuI}: 62 \mathrm{~mm}-25 \mathrm{JuI}: 64 \mathrm{~mm}$ 3 Aug : $80 \mathrm{~mm}$. Total water supply: $367 \mathrm{~mm}$

At 2-3 trusses per plant time, mechanical weeding with placement of $40 \mathrm{~N} \mathrm{ha-1} \mathrm{(ammonium} \mathrm{nitrate)} \mathrm{on.} \mathrm{Iows,}$ partial hand weeding on rows, $17 \mathrm{Jun}$

Metribuzin (500 $\mathrm{g} \mathrm{ha}^{-1}$ ) at half flowering time, $12 \mathrm{Jul}$

Partial hand weeding (Solanum nigrum), 5 Aug

Bacillus thuringiensis spray, $22 \mathrm{Jul}$

Bacillus thuringiensis spray, $29 \mathrm{Jul}$

Fongicide (chlorothalonil), $31 \mathrm{Jul}$

Ethephon spray at $50 \%$ red + pink fruit time, 21 Aug

Mechanical harvest, 11 Sep. yield: 78 tha-1 


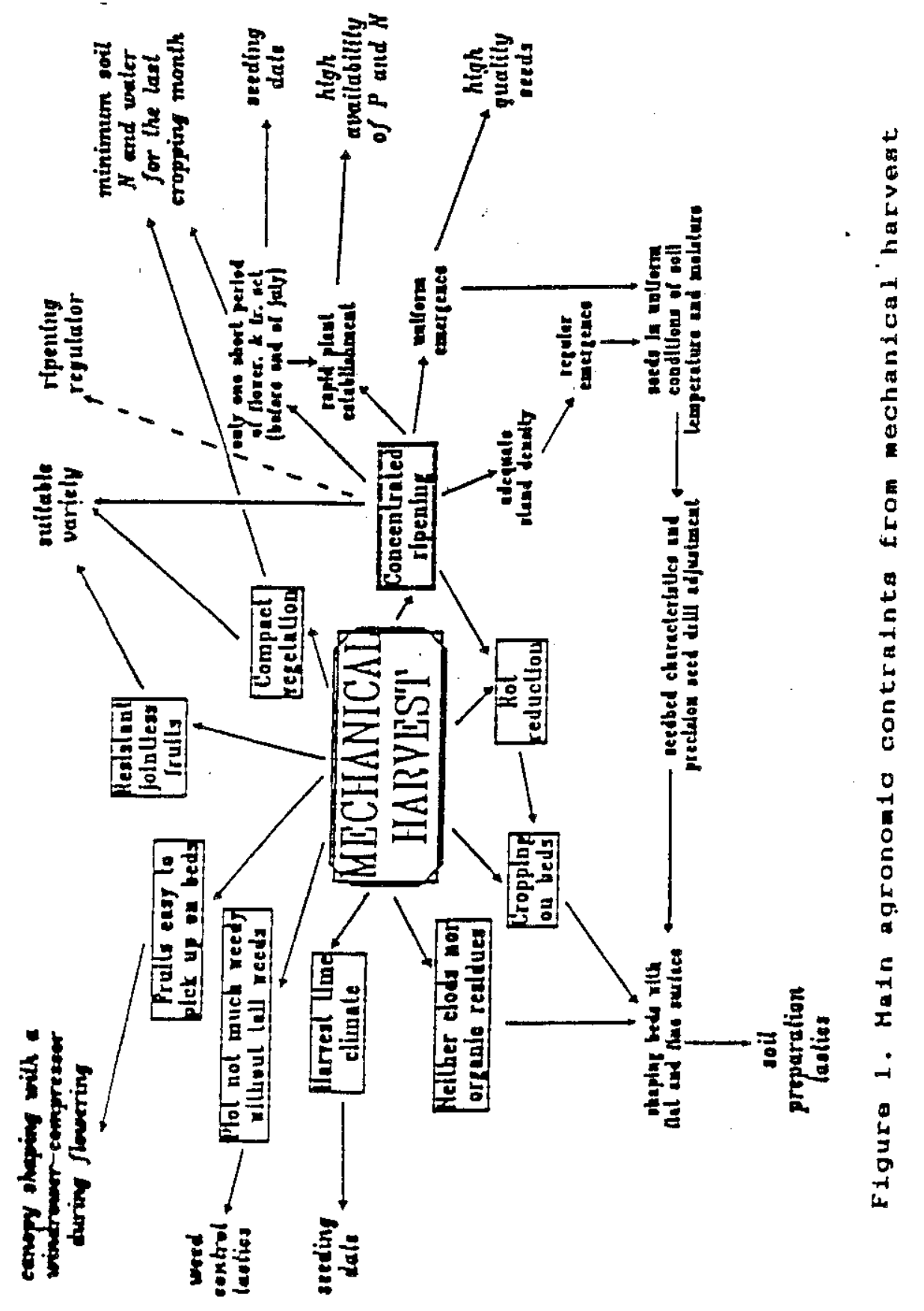




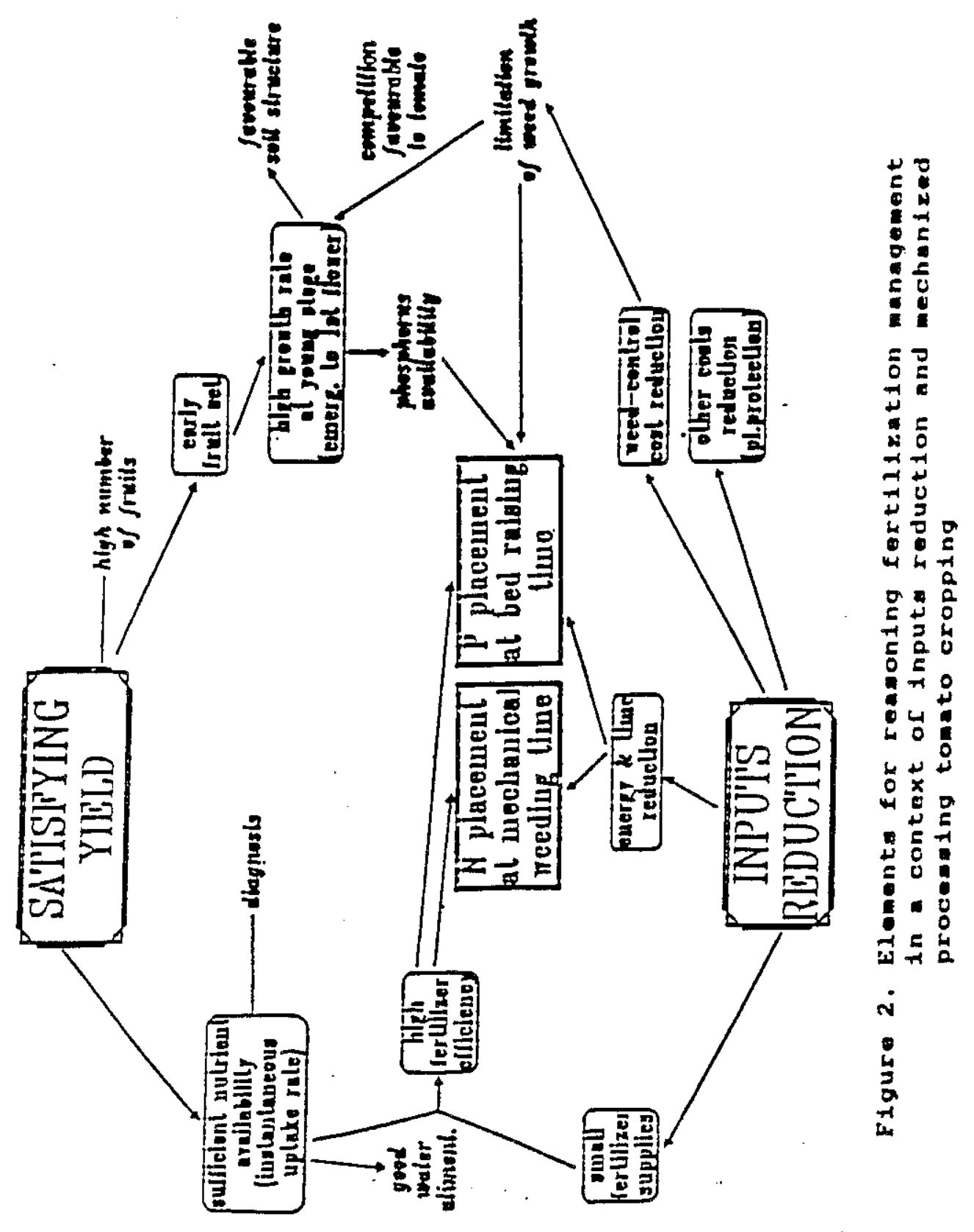

